\title{
Research on the Employment of Normal College Students
}

\author{
Jichuan Li \\ Linyi University \\ Linyi, China 273400
}

\begin{abstract}
Normal college students are a special group of college students. Under the conditions of market economy, major changes have taken place in the pattern of employment of normal college students. The employment situation of normal college students has been accurately grasped, and the factors that affect the employment of normal college students have been analyzed. The leading role of the government has been actively promoted. It should strengthen normal college students' employment, strengthen the guidance of college students' professional values, establish a correct occupation outlook on the concept of career values, consolidate the foundation, strengthen internal quality, develop in an allround way, and increase self-confidence in job selection.
\end{abstract}

Keywords-normal college students; employment; influencing factors; research on the problems

\section{INTRODUCTION}

With the transformation of China's economic system from planned economy to market economy, the graduate employment system in China has also undergone the transition from "planned distribution" to "market-oriented, government-controlled, and student-employer selection." At the same time, with the transformation from the elitism of higher education to popularization of higher education, the employment conflict among college graduates has become increasingly prominent. The employment of college graduates has become the issue concerned by the government, society, schools, families and students. And it has become social problem. According to statistics from the National Ministry of Education, the number of college graduates nationwide has reached 6.11 million in 2009, including more than 600,000 normal college graduates, accounting for $10 \%$ of the total number of college graduates. It has the actual situation of oversupply and employment difficulties for college graduates. Due to the influence of factors such as the concept of employment of normal college students, teacher education major, backward adjustment of discipline structure, low-level training in teacher education, backward reform of social employment mechanism and personnel system, and imperfect employment information consultation and guidance services, the employment situation faced by normal college graduates is even more severe. Therefore, it is of great significance to study the employment of normal college students and explore the new employment model of normal college students. It is of great significance to the government decision-making, the teaching reform of teachers' education, the employers' changing employment concept, and the self-learning and image-building of normal college students.

\section{INFLUENCING FACTORS OF THE EMPLOYMENT OF NORMAL COLLEGE STUDENTS}

With the expansion of college enrollment, China's higher education has changed from "elite education" to "mass education". On the one hand, the popularization of higher education has broadened the scope of education. It would be helpful to achieve educational equity. On the other hand, the employment of students shows a downward trend. The author would analyze the reasons from four aspects: society, college, family and students.

\section{A. The Society}

From the analysis of social factors, the factors that affect the employment of normal college students mainly include: economic growth, employment system, employment market, employment channels, and so on.

The slower economic growth has affected the employment of normal graduates. In recent years, due to the impact of European debt crisis and domestic supply and demand, China's economic growth rate has slowed down year by year. It has reduced the number of jobs for which the society absorbs employment. The employment opportunities of college graduates are bound to be affected accordingly. Combined with the use of new technologies, new energy sources, new materials and new technologies, labor productivity has increased substantially. The number of social laborers has gradually decreased. And employment indicators for schools and other public institutions have also been reduced year by year, which is bound to adversely affect the employment of normal college students.

The reform of the employment system has changed the way that normal college students apply for jobs. First of all, the changes in the employment system in China have changed the pattern of employment for normal college students. The past unified distribution system has been replaced by the "examination for entry" model. In addition to some private education, normal college students must go through unified examinations when entering educational institutions. Undoubtedly, it has increased the difficulty of employment for normal college students. Secondly, with the 
implementation of teacher qualification system and the gradual improvement in the treatment of teachers, the similar secure jobs such as teachers, and the "examination for entry" system for selecting and employing people have made it possible for talents who are willing to be teachers to gather in schools to have the examination. They make unremitting efforts to get the jobs. It also increases the pressure on the employment of normal graduates.

The imperfect job market has hindered the solution of the employment of normal graduates. The total number of normal college students in the job market is increasing year by year. It is impossible for normal college students to enter the education sector. Because the professional characteristics of normal college students, they do not have obvious expertise. When they cannot be a teacher, it is difficult to compete with other professionals in job market for normal college students. Normal graduates who don't want to be teachers can't find the ideal job as soon as possible, to a certain extent. This has affected the solution of the employment for normal graduates.

\section{B. The School}

The colleges and universities are the main venue to make pre-service education for normal college students. The colleges and universities have great influences on the employment of normal graduates. Viewing the employment of normal graduates from the perspective of teacher education, the factor of college mainly includes: curriculum setting, employment guidance and so on.

Unreasonable curriculum setting affects the employment of normal graduates. At present, the curriculum of teacher education is centered on disciplines, ignoring the training of educational theories and educational practice abilities. It is out of line with social needs. It also seldom involves courses other than the teacher education major. And it rarely designs the courses of entrepreneurship and employment. From the perspective of world and national curriculum reform trends, comprehensive curriculum design and students' employment have become key points in the curriculum reform of all levels of colleges in China today.

The weakening of employment guidance has made it difficult for normal college students to face employment. It lacks employment guidance. The employment guidance courses are formal and superficial. They are not targeted, and lack the effectiveness. The employment of graduates is at a loss. The pessimism of "graduation means unemployment" exists universally. There has been an increase in the number of "school drifters" lingering in colleges and society. There is an increase in mental confusion, psychological pressure and various psychological barriers in the group of normal college students. They cannot be effectively overcame and resolved. And some normal college students are ignorant of the needs of the talent market. The urgent need for employment guidance is in stark contrast to the lags and low energy of employment guidance.

\section{The Family}

The factors of family mainly include the expectations of parents, occupation, status and social skills, parent-child relationship, family environment and atmosphere.

1) The professional psychological expectations of holding high hopes for their children: They have expectations on their children rather than themselves. They hope that their children would obtain success in their studies and careers. It is the common wish of each parent to cultivate the children to be outstanding figure. Therefore, regardless of the status of the parents, they want their children to be "victorious" over themselves. Therefore, this kind of psychology is undoubtedly demonstrated in action. And it has imperceptible influences on students' employment.

2) Professional nature of "a good scholar making an official": The current generation of parents of normal college student is mostly born in the $60 \mathrm{~s}-70 \mathrm{~s}$ of the last century. They value the nature of the careers. Most parents hope that normal college students will work in public schools after graduating. And they do not want their children to go to private educational institutions or other industries. To a certain extent, it has affected the employment of normal college students.

\section{The Students}

Normal college students belong to high-quality talents. The employment expectation is relatively high. And normal college students are unwilling to accept less, which exists extensively. It is an important factor affecting the employment of normal college students.

Competence quality is incompatible with market needs. With the advent of the era of knowledge-based economy, higher requirements have been placed on the quality and ability of talents. However, because of the education system and the reasons for normal college students, the ability and quality of contemporary normal college students cannot adapt to the needs of the market. First of all, the structure of abilities of some normal college students is not perfect. In terms of knowledge structure, normal school students have more theoretical knowledge and less practical ability. Therefore, when normal college students are in the work position, they would have more theoretical knowledge rather than practical ability. And they can't get started the work immediately.

The development of capacity is not comprehensive. Normal college students only focus on the study of professional knowledge while ignoring the learning of other skills related to the teaching profession. Many normal college students only know how to upload knowledge in the classroom. And they are less capable of carrying out ideological education and working as head teachers. .

Normal college students lack of emotional intelligence and communication. With bad communication, they can't improve themselves. When normal college students are looking for a job, they will not be able to boldly express 
themselves. And they will not be able to seize the opportunity. Then, they would miss the opportunity. There are also some normal college students who do not have social experience. They are not able to correctly position themselves. They are less familiar with the society. They would ignore actual conditions, or blindly ask for big ones, replace the reality with imagination. Then, they don't have sufficient courage to face reality and challenges.

\section{COUNTERMEASURES FOR EMPLOYMENT OF NORMAL COLLEGE STUDENTS}

\section{A. To Actively Play the Leading Role of the Government and Make Intensify Efforts to Promote the Employment of Normal College Students}

Under the conditions of market economy, talents are allocated through market demand. To independently choose the career are the requirements of the market economy and the normal state of employment for normal school students. However, due to the special purpose of training for normal graduates, the government should deal with normal college students' employment to take a series of measures to ensure and promote students' employment under the general policy of "autonomous employment of laborers, market adjusting employment and the government promoting employment".

The government should formulate policies that are suitable for the employment of normal college students. The teacher profession has different characteristics from other professions. The professional goal of the teacher profession is to train qualified teachers in primary and secondary schools. Its professional learning is based on professional knowledge and professional skills of teachers. The colleges and universities pay attention to the cultivation of other professional qualities of normal college students. However, many of them are limited to the education of innovation and entrepreneurship. And their focus is on professional education. Therefore, the employment of normal college students is different from that of other professions. Local governments should formulate suitable employment policies based on their professional characteristics to ensure that excellent teachers enter the education field.

\section{B. To Strengthen the Guidance of College Students' Professional Values and Establish Correct Career Outlook}

The concrete manifestations of life goals and life attitudes in career selection are the recognition of occupations, attitudes, and pursuit of career goals. They are the embodiment of mainstream social values. The values advocated by the socialist market economy do not negate the realization of individual social values. However, it would advocate the society-based values of devoting youth to the rejuvenation of the country and nation. Therefore, to make the contribution to the society is still the premise and basis for normal graduates to complete job selection. Normal colleges and universities should strengthen their education of world outlook, outlook on life and values. They would lead professional values through their "three views". It should achieve the organic unity of self-value and social value.
World outlook, outlook on life and values has directing and regulating effects on people's behavior. Teacher education majors in colleges and universities should strengthen the education of students' world outlook, outlook on life and values through ideological and political lessons, group lectures, community clubs, and lectures, etc. And normal college students can properly handle the relationship among the interests of the state, the collective and the individuals. The normal graduates would achieve two combinations in employment: namely, the combination of self-development and social needs, and the combination of career choices and the needs of the times. From an individual perspective, normal graduates often consider social and personal characteristics, their own professional development, wages and benefits and working conditions. They would pay more attention to social responsibility and social contributions from social perspective. The former reflects the value orientation of individual's job selection. And it is a true portrayal of the individual's "three views". The latter is the inevitable value orientation of the state and society for normal graduates in all levels of society. Therefore, the normal graduates can coordinate the ingenuity and pursuit of lofty ideals. In the unity of their own development and the needs of the times, they must reasonably position the profession, define the direction of career development, and form an active and healthy professional attitude. And then, they would realize the value of life.

\section{To Strengthen the Foundation, Internal Quality and All- round Development, and Increase Self-confidence in Job Selection}

The job market is characterized by competition, fairness and equality as in the general market. Competitiveness shows that the job market is fierce. Sometime, it is still cruel. And fairness and equality reflect that the job market can provide equal opportunities for all competitors. According to a large number of employment practices, the bottleneck that restricts the employment of normal graduates is strength. The employment level of normal college students depends on the development degree of the comprehensive quality of normal graduates and the strength of their ability. Therefore, colleges and universities need to educate normal graduates to take social demand as the orientation, broaden basic knowledge as their basic goal, and use scientific research ability and practical ability as the goal. The colleges and universities must improve comprehensive literacy in aspects such as ideology, morality, cultural level, professional knowledge, and physical and mental health, practical work abilities such as training, social interaction, etc. They should focus on the employment market to strengthen students' sense of innovation and competition, and improve the quality of employment and the level of employment.

\section{CONCLUSION}

The employment of normal college students is the same as the overall employment of college students. It is not only a social and economic problem. At the same time, it is also a political issue. Therefore, the solution to the employment of 
normal college students is not only beneficial to the needs of normal college students, but also conducive to social stability.

\section{REFERENCES}

[1] Pei Lizhi. Research on the Development of Higher Teacher Education in Anhui Province [D]. Anhui University, 2011 裴立志. 安徽省高等 师范教育发展问题研究[D]. 安徽大学, 2011

[2] Wu Zhongyu. Research on the Status Quo and Improvement of the Employment of Normal College Students in Guangxi Province [D]. East China Normal University, 2011 伍钟玉. 广西师范生就业力发 展现状及改进研究[D]. 华东师范大学, 2011

[3] Jia Jinfeng. Research on the Current Situation and Development of Higher Education in China [D]. Northwest University, 2008. 贾晋锋. 我国高等师范教育的现状及发展思路研究 [D]. 西北大学, 2008 .

[4] Zhao Wenwen. Study on the Imbalance of Supply and Demand Structure of Normal Graduates in Western China [D], Sichuan Normal University, 2009. 赵雯雯. 我国西部地区高等师范院校毕 业生的供求结构失衡问题研究 [D], 四川师范大学, 2009 .

[5] Yang Zhiqiu. An Analysis of the Employment for Normal College Students [J]. Journal of Anshan Normal University, 2010, (05) 杨志 秋. 师范生就业问题探析 [J]. 鞍山师范学院学报, 2010, (05) 